LEAD:TOXICITY AND TISSUE LEVELS IN THE EMBRYO.Joseph Kochen* \& Yigal Greener*,Albert Einstein Col.of Med.,Montefiore Hosp. \& Med.Ctr , Dept.Ped.,Bronx, New York (Intr. by Laurence Finberg)

Lead $(\mathrm{Pb})$ injected into yolk sacs of day 4 chick embryos results in progressive central nervous system(CNS) bleeding which subsides by day 10-12 and is followed by the development of hydrocephalus. The use of $\mathrm{Pb} 210$ permitted a correlation between the dose of $\mathrm{Pb}$, tissue $\mathrm{Pb}$ levels,morbidity, and mortality. Increasing the $\mathrm{Pb}$ dose resulted in increasing CNS damage, mortality, and increasing concentrations of total body, blood and brain $\mathrm{Pb}$. Injection of $\mathrm{Pb}$ after day 11 was accompanied by a marked decrease in morbidity and mortality. This was associated with reduced brain $\mathrm{Pb}$ concentrations, but no decrease in blood $\mathrm{Pb}$ levels.This indicates the development of a blood-brain barrier to $\mathrm{Pb}$ at this period in development and corresponds to the for mation of specialized endothelial junctions in the CNS. Administration of Ca Edta at intervals after $\mathrm{Pb}$ injection on day 4 enabled delineation of the minimum period required for the occurrence of $\mathrm{Pb}$ toxicity. Edta given 2 minutes after $\mathrm{Pb}$ resulted in complete protection against $\mathrm{Pb}$ induced CNS damage an mortality. At intervals up to 8 hours there was a substantial diminution in morbidity and mortality. At longer intervals lit tle protection was afforded by Edta. Blood and body $\mathrm{Pb}$ levels remained unchanged, irrespective of Edta administration; however, brain $\mathrm{Pb}$ levels increased with increasing Pb-Edta intervals. These results demonstrate a relationship between CNS damage and brain Pb levels and indicate that a brief exposure to $\mathrm{Pb}$ early in development suffices to produce CNS damage and embryo death.

BMR, DNA AND CELL SIZE IN PRE- AND POSTNATALLY DEPRIVED RATS Ingeborg Krieger and Oamar Taq1, Wayne State Univ. School of Mediclne; Children's Hospital of Michigan, Detrolt.

In infants BMRs are lower in prenatal than in postnatal onset growth fatlure. The signiftcance of this was investigated In rats with similar types of growth fallure by relating their BMR to body velght (BWt), combined organ ( 0 : liver, kfdney, heart, and brafn) welght (OWt), DNA (ODNA), and protein (OPr). Mature rats were fed a $6 \%$ protein diet 1 month prior to and during mating, gestation, and lactation. Offsprings were fed $27 \%$ protein at weaning (A). Offsprings of normal rats were fed low protein from weaning to 10 weeks and high protein up to weight recovery (B). The Insult caused permanent stunting in group A rats; $3 / 4$ of group B rats had normal weights by 24 weeks. Sleep1ng BMRs were measured in 4 rats of each group before sacrificing, at weaning, 10,16, and $>16$ weeks, and in 11tter-mates weekly up to maturity. The relation of the BMR with BWt, OWt, and OPr was curvi-linear; that with ODNA was 11near. These relations were similar for normal controls. The BRR per BWt, OWt, and OPr decreased with age as cell size increased. The insults affected ODNA and OPr of 11ver, kidney, and heart in both groups but not of brain. Recovery paralleled weight recovery. Recovery of cell size occurred first. The data show that the BMR reflects cell number rather than cell mass. Comparison of the BMRs suggests that the Insult of group A rats was not comparable to that which caused dwarfing in Infants with growth fallure of prenatal onset.

\section{INFORMATION TRANSFER BY CELLULAR MESSENGER RNA}

Lee H. Kronenberg and Theodore Friedmann Department of Pediatrics, School of Medicine University of California at San Diego La Jolla, California 92037

Total cell RNA purified from cultured mouse cells induced to synthesize interferon causes mouse interferon synthesis in heterospecific cell cultures. Metabolic and physicochemical criteria support the conclusion that genetic information is transferred as the messenger RNA (mRNA) for mouse interferon. The species specificity and physicochemical properties of the product suggest that it is mouse interferon. These results confirm the report by De Maeyer, De Maeyer-Guignard and Montagnier (Proc. Natl. Acad. Sci.,69, 1203 (1972)). By means of RNA transfer, we have devised a relative quantitative assay for interferon mRNA activity. Because the biological activity of the mRNA can be assayed, new opportunities exist for the study of the control of a specified gene and the metabolism of a specific messenger RNA.
AGE-DEPENDENT ACTIVITY OF L-GLUTAMIC ACID DECARBOXYLASE (GAD) IN HUMAN KIDNEY. G. A. Lancaster, F. Mohyuddin \& C.R. Scriver. \& McGill Univ. Montreal. The conversion of $\mathrm{L}-\mathrm{glutamate}(\mathrm{L}-\mathrm{glu})$ to $\gamma$-aminobutyrate (GABA) in mammalian brain \& kidney is catalyzed by pyridoxal-phosphate (PIP)-dependent GAD. GABA is an important neuro-inhibitor in CNS, but another role must exist for GABA metabolism in kidney cortex. We assayed GAD by an isotopic method (Lancaster et al, BBA 297:229,1973) at normal tissue $\mathrm{L}-\mathrm{glu}$ conc. $(4-8 \mathrm{mM}) \pm \mathrm{PL} \quad(0.24 \mathrm{mM})$ in frozen postmortem human kidney obtained between 15wk gestation and loyr.GAD is stable in tissues or homogenates stored at $-20^{\circ} \mathrm{C}$; PLP-saturated renal GAD activity is low ( $<0.5$ nmoles $\mathrm{CO}_{2}$ formed/mg wet $\mathrm{wt} \cdot \mathrm{h}$ ) before $40 \mathrm{wks}$ gestation, then rises at term and plateaus in the infant \& child at 5-10x fetal level. Kidney GABA conc. parallels GAD activity. Endogenous GAD activity is often inappropriately low for age, but can be stimulated by PLP in vitro, indicating, undersaturation by co-enzyme in vivo; once bound in vivo, PLP is not easily removed from GAD in vitro. Augmentation of renal GAD activity at term parallels the need for human kidney to extract glutamine from plasma to support renal ammoniagenesis. The GABA pathway permits disposal of the residual glutamate carbon chain as a non-titratable acid.

PHARMACOKINETICS OF DICLOXACILLIN IN PATIENTS WITH CYSTIC FIBROSIS. Mary E. Mattar, William J. Jusko, Louise Gerbracht, Luis Mosovich and Sumer J. Yaffe. Department of Pediat

The frequent episodes of peribronchial pneumonia seen in patients with cystic fibrosis require antibiotic administration often with anti-staphylococcal agents. Until now the data upon which to base dosage regimens have not been available. Serum dicloxacillin concentrations and urinary excretion rates were measured in 10 patients ranging in age from 9 to 22 years and in 5 normal adult subjects at various times after oral administration of a single dose $(6.25 \mathrm{mg} / \mathrm{kg})$ of antibiotic suspension in order to investigate absorption and disposition kinetics. The disease did not appear to cause impaired absorption of the antibiotic since the total urinary recovery: of the drug in the patients usually exceeded that of normal subjects. However, the peak plasma levels and areas under the concentration versus time curves of dicloxacillin were much lower and more variable in the patients than in the normal subjects. Less antibiotic is therefore available for therapeutic effect. This was the result of unusually high renal clearances of dicloxacillin ( $3 x$ norma 1 ). It was significant that the dicloxacillin :creatinine clearance ratios ( 1.55 versus 0.87 , respectively) were larger in the patients than in normal subjects. Because of this rapid renal excretion, treatment of cystic fibrosis patients with dicloxacillin warrants use of increased doses. Measurements of the serum concentration of the antibiotic may be needed to assure adequacy of therapy.

ONTOGENY OF TRACHEAL FLUID, PULMONARY SURFACTANT AND PLASMA CORTISOL IN THE FETAL LAMB. E. Joseph Nescher, Arnold C.G. Platzker, Philip L. Ballard, Joseph A. Kitterman, John A. Clements and William H. Tooley. Spec. Ctr. of Res., PuIm. Dis. and Dept of Ped., Univ. of Calif, San Francisco, Calif. We examined fetal plasma cortisol and the flow rate, electrolyte composition and surfactant content of tracheal fluid in chronic experiments with 9 fetal sheep. We catheterized a fetal artery and inserted a tracheal catheter to divert fluid into an intrauterine bag which was emptied every $12 \mathrm{hr}$. Surfactant was assayed on a surface balance and cortisol was determined by the protein binding radioassay. From $120-150$ days of gestation there was no change in mean fluid $\mathrm{Na}^{+}$( $\left.149 \mathrm{meq} / \mathrm{L}\right), \mathrm{Cl}^{-}(153.9 / \mathrm{meq} / \mathrm{L}), \mathrm{Ca}^{++}(2.2 \mathrm{mg} / 100 \mathrm{ml})$ and $\mathrm{pH}(6.21)$. The rate of fluid production was $4.5 \mathrm{ml} / \mathrm{Kg} / \mathrm{hr}$. $\mathrm{K}^{+}$increased from $4 \mathrm{meq} / \mathrm{L}$ at $120-130$ days + to about $9_{+} \mathrm{meq} / \mathrm{L}$ ( $145-150$ days) while plasma $\mathrm{Na}^{+}, \mathrm{Cl}^{-}, \mathrm{Ca}^{++}, \mathrm{pH}$ and $\mathrm{K}^{+}$were constant at $146 \mathrm{meq} / \mathrm{L}, 109.1 \mathrm{meq} / \mathrm{L}, 12 \mathrm{mg} / 100 \mathrm{ml}, 7.4$ and $4.3 \mathrm{meq} / \mathrm{L}$, respectively. Cortisol was less than $1.5 \mu \mathrm{g} / 100$ $\mathrm{ml}$ total $(0.3 \mu \mathrm{g} / 100 \mathrm{ml}$ free) until, 'n days when it increased rapidly to 10.5 total $(3.2$ tree) at $148 \mathrm{u}$.'s. Surfactant first was detected in tracheal fluid betweer, $25-130$ days and increased exponentiaily after 135 days to a value of $200 \mu \mathrm{g} /$ $\mathrm{Kg} / \mathrm{hr}$ af 147 days. Thus, fluid:Dlasma gradients exist for $\mathrm{Cl}^{-}$, $\mathrm{Ca}_{+}, \mathrm{H}^{+}$and, in late gestation, $\mathrm{K}^{+}$. It appears that an increase in fetal cortisol is not the stimulus for appearan:e of surfactant in the lamb, although this hormone may induce the rapid accumulation of surfactant prior to delivery. 